\title{
Influence of Auditing Practices on Financial Distress in Selected County Governments, Kenya
}

\author{
John Muthini Ndunda $^{1 *} \quad$ Prof. Willy Muturi ${ }^{1} \quad$ Dr. Daniel Wanyoike ${ }^{2}$ \\ 1.School of Business, Jomo Kenyatta University of Agriculture and Technology, P.o. Box, 1063, Nakuru, Kenya \\ 2.School of Entrepreneurship, Procurement and Management, Jomo Kenyatta University of Agriculture and \\ Technology, P.o. Box, 1063, Nakuru, Kenya
}

\begin{abstract}
County Governments of Kenya have been hit with rampant embezzlement of public funds. The misuse of public financial resources has crippled service delivery to the people as well as payments to suppliers and creditors. The role of auditing practices is to enhance accountability and safeguard the public funds from being mismanaged. However, there is an evident lack of clarity in the effectiveness of existing auditing practices in Kenyan County Governments. The consistent misplaced expenditures have contributed to financial distress since most County Governments are unable to adequately meet their financial obligations. This necessitated the undertaking of a research study on the influence of auditing practices on financial distress in County Governments of Kenya. The study was guided by the theory of critical accounting. Descriptive survey design was employed to obtain in-depth information from the auditors and accountants from Nairobi, Nakuru, Kakamega, Meru, and Kilifi County Governments. A stratified random sampling technique was applied to obtain a sample of 103 respondents from 212 auditors and accountants. Structured questionnaires were used to collect data that was analyzed through descriptive and inferential statistics with the aid of statistical packages for social sciences (SPSS). Study findings were presented through tables. Both descriptive and inferential findings showed that auditing practices influenced financial distress. Correlation analysis findings indicated that the relationship between auditing practices and financial distress was positive and statistically significant. The correlation coefficient was $\left(\mathrm{R}=0.455^{* *}\right)$ while coefficient of determination was $\left(\mathrm{R}^{2}=0.207\right)$ which meant that auditing practices accounted for $20.7 \%$ of variations in financial distress. Regression coefficients further showed that auditing practices had beta coefficient $(\beta=0.360$; $\mathrm{p}=0.000$ ) that was significant at $95 \%$ confidence level. Based on the findings, it can be concluded that the ability of County Governments to settle their financial obligations and other liabilities is dependent on effectiveness of auditing practices. Existing financial distress can therefore be attributed to inadequate auditing practices which are unable to promote accountability and effective use of public funds. The study findings will be valuable in guiding the establishment and implementation of effective auditing policies for County Governments.
\end{abstract}

Keywords: Auditing Practices, Financial Distress, County Governments

DOI: $10.7176 /$ RJFA/11-14-10

Publication date:July $31^{\text {st }} 2020$

\section{Introduction}

Auditing Practices are critical dimensions of financial management in the government sector (Alcaide-Munoz, Rodriguez-Bolivar, \& Lopez-Hernandez, 2017). They determine accountability in the activities performed by the County governments. The cornerstone of the county governments' operations is sourcing and using public funds while involving the residents, employees, the suppliers, and creditors in the provision of services (Njonde \& Kimanzi, 2014). The suppliers supply products to the County governments to enable them serve the people. County governments also acquire loans and grants to boost their revenue and deliver services as expected by people. However, misuse of financial resources by the County Governments leaves them with little funds to pay creditors and suppliers. Insufficient funds also mean that they delay the employees' salaries leading to unrest and poor service delivery to the residents. According to Odoyo, Adero, and Chumba (2014) auditing practices are meant to make County Governments accountable in managing public funds and make due payments as required. However, ineffective auditing practices imply that mismanagement of public funds could go unnoticed, and in the end, the County Governments cannot settle their financial obligations hence becoming financially distressed. Auditing practices provide assessments that are objective on the way public funds are managed (Hague \& Harrop, 2013). Financial resources ought to be utilized effectively to achieve the intended outcomes; thus, auditing is responsible for promoting integrity and accountability in County governments. Proper accounting for public funds influences transparency and accountability and foster confidence in the public sector (Bandy, 2014). Financial management helps local governments to prioritize and reconcile unlimited demands and needs with limited financial resources. Local government is financially sustainable when it can generate sufficient revenues to perform its fundamental function and deliver some core services up to a minimum acceptable level (Alcaide-Munoz et al., 2017). However, unsustainable governments are financially distressed. Financial resources' insufficiency is a common challenge among local governments globally, and the problem is even more significant in developing countries. 


\subsection{Statement of the Problem}

County Governments of Kenya are expected to provide services at grassroots levels through effective use of public financial resources. Provision of public services depend on financial management by County Governments, in terms of accountability in use of public funds. Auditing practices promote effective management and accountability in use of financial resources. However, there is rampant embezzlement of public funds among County Governments in Kenya. Mismanagement and misuse of resources has deterred County Governments from meeting their obligations in terms of service delivery and payments to suppliers and creditors. Therefore, there is a major concern on the effectiveness of existing auditing practices. The consistent misplaced expenditures have contributed to financial distress since most County Governments cannot settle their liability obligations. They have not been able to settle their liabilities, such as payment of salaries and debts owed to contractors and suppliers hence forced to operate on huge debts that attract higher interest rates due to failure to settle bank loans. This situation has led to financial distress painting a bad picture of the devolution in Kenya. Financial distress has been experienced in counties whereby employees' dues have been delayed on many occasions leading to numerous strikes, especially in the health departments. This problem has been persistent, resulting in stalling of major county initiatives; hence devolution expectations are yet to be sufficiently realized in the Country. The current study determined the influence of auditing practices on financial distress in County Governments of Kenya.

\subsection{Objective of the study}

The objective of the study was to determine the influence of auditing practices on financial distress in county governments of Kenya.

\subsection{Research Hypothesis}

H01: Auditing practices does not significantly influence financial distress in county governments of Kenya.

\section{Literature Review}

\subsection{Theoretical Review}

The study was guided by the theory of critical accounting which explained the auditing practices and financial distress.

\section{Theory of Critical Accounting}

The theory of critical accounting describes the stewardship of public money whereby local governments are required to ensure that public funds are used in a way that residents will benefit (Jacobs, 2012). Therefore, these institutions have internal audit sections tasked with investigation and verification of financial statements, thus determining the utilization of the available financial resources. The theory of critical accounting further instigates that control and compliance in county governments are aimed at eliminating unnecessary expenditures, which can result in wastage of public money as well as corruption practices, thus advocating for appropriate audit mechanisms. According to Brown and Dillard (2011), financial managers are required to handle financial resources with care and should exhibit honesty while reporting usage of the funds. There should be an effective relationship between county governments and the residents that they are serving about financial accountability to track the government's expenditures and their significance to the people. County governments ought to establish appropriate accounting and auditing systems, but these items can only be effective when financial accountability has been achieved. The financial and operational environment of county governments influences their financial performance and difficulties in equal measures.

The organization's culture also influences the local governments' accounting environment, thus the need for improved awareness of factors influencing the organization's financial activities and accountability systems (Lehman, 2010). Compatibility between accounting control systems and organizational culture is crucial in combating financial distress in local governments. The nature of accounting personnel, financial management information system, and public sector accounting and auditing standards influences the effectiveness of financial accountability hence financial distress. The effectiveness of the financial accountability of county governments is influenced by the efficiency of the budget process, financial reporting system, and audit processes. On the other hand, if there is a poor budget process, financial reporting, and ineffective external oversight, there will be corruption and mismanagement, which will lead to financial distress (Brown \& Dillard, 2011). Internal audit units review the means of safeguarding assets and, where appropriate, verify the existence of such assets (Yilmz, Beris, \& Serrano-Berthet, 2009). Critical accountants and auditors over the world prefer new and enabling forms of auditing and accounting in government agencies to foster transformative accounting to bring justice and fairness regarding public funds (Brown \& Dillard, 2013). County/local governments have to establish and implement critical accounting policies to keep track of their financial positions to enable them to make informed decisions concerning budgets and expenditures. 


\subsection{Conceptual Framework}

The conceptual framework outlines the presumed association between the independent variables and dependent variable. Figure 2.1 illustrates the relationship between auditing practices and financial distress.

\begin{tabular}{|c|c|}
\hline $\begin{array}{l}\text { Auditing practices } \\
\text { Internal audit practices } \\
\text { - } \quad \text { Risk assessment } \\
\text { - Improved governance } \\
\text { - Financial control frameworks } \\
\text { External audit practices } \\
\text { - Assessment of regulatory compliance } \\
\text { - Investigation into reporting Standards } \\
\text { - } \quad \text { Financial Supervisory activities }\end{array}$ & $\begin{array}{ll}\text { Financial Distress } \\
\text { - } & \text { Effectiveness in } \\
& \text { delivery } \\
\text { - } & \text { Level of Budgetary Solvency } \\
\text { - } & \text { Strength of revenue base }\end{array}$ \\
\hline
\end{tabular}

\section{Independent Variable}

\section{Dependent Variable}

\section{Figure 2.1: Conceptual Framework}

\subsection{Auditing Practices}

Auditing practices in local governments are meant for control, good governance, and risk management (Lin, Yang, \& Wang, 2018). They ensure effective management of public revenue and expenditure, thus efficiency within local governments by aiding internal control systems. Auditing practices in local governments are usually undertaken by internal auditors and supervisory organs from the office of auditor general in the central governments. These people are required to exhibit high standards of professionalism in their respective duties to ensure the accountability of the government's financial resources. Therefore, competent and qualified personnel are needed for the audit sections to ensure that county officials are accountable and compliant.

Scoeman (2011) opined that regular and independent examination of the books of accounts by qualified auditors are a requirement to ensure that the statement of account as recorded represents an accurate and fair view of all the transactions as during the period under investigation. Furthermore, sanity is provided regarding the management of the County's finances while continuing to provide core economic functions, even during severe but plausible shocks. In a resilient system, individual institutions in distress should be resolvable with minimal costs to the residents, business people who are the taxpayers. The major problem facing auditing function in local authorities is inadequate facilities to monitor all the roles, poor segregation of duties, and lack of independence of the internal auditors. Inadequate records and financial systems, and interference by the politicians also affect auditing.

Internal auditing involves appraisal activity established by management for the review of accounting and internal control systems as a service to the entity (Lin et al., 2018). Independent and effective supervisory mechanisms must be capable of preventing or combating malpractice regardless of a kind of leadership in place to help minimize incidences of incompetence or sheer dereliction of duty. Internal controls in the accounting system serve the function of ensuring that all transactions carried out are suctioned that authorized by management. Auditing ensures the goals and objectives of a financial institution are properly met, that the company will achieve long-term profitability targets and maintain reliable financial and managerial reporting system of strong internal controls must be in place (Scoeman, 2011). County governments should continuously and periodically evaluate the effectiveness of their internal controls. Establishment of an efficient and effective internal audit department involves huge cost, but if analyzed critically, the benefits of an internal audit unit to an organization outweighs the cost. Internal audit improves efficiency, creates control, which acts as a deterrent to inefficiency, waste, and fraud.

Kuhlmann and Bogumil (2018) noted that budgetary problems in local governments are caused by a lack of effective communication between local government officers. The study further stated that inadequate auditing and poor reporting standards in municipalities contributed to financial distress and a significant signal to bankruptcy. Available technological tools were not appropriately utilized to track the local government's finances; thus, problems associated with fiscal distress were not detected earlier to provide room for correction. Instead, the significant focus was on the short term views concerning budget portraying temporary survival mode. Budgetary issues and technology concerning local government's finances require proper fiscal policies in place for full implementation, but this was not discussed in the study. Moreover, it lacks the platforms that should guide the excellent working relationship between municipality officers and thus, appropriate communication between them that can help them notice mistakes among themselves and rectify them.

The starting point of any capacity development planning process is assessing existing capacity (Unegbu, 2011). Organizational levels are framed in terms of performance and results, and at the institutional level in terms 
of conditions, but there may be overlap between these categories. Auditor's opinion is the ultimate result of the accountant's investigative work in county governments. Whether the auditor reports the deficiencies of the local government's financial resources depends on some considerations, such as the fact that improper opinions may affect the costs. Therefore, the quality of audit opinions must be assessed. Auditor opinions are used to measure the independence of auditors in a firm. Internal and external auditors as financial audits, performance audits, investigations, and advisory services (Lekamario, 2017)). An effective public sector audit activity promotes citizens' ability to hold their public sector entity accountable. They are critical in promoting credibility, equity, and appropriate behaviour of public sector officials while reducing the risk of public corruption. Therefore, it is crucial that audit activities are configured appropriately and have a broad mandate to achieve these objectives. The audit activity must be empowered to act with integrity and produce reliable services, although the specific means by which auditors achieve these goals vary.

Supervision of the financial transactions of government-owned organizations is essential as far as performance is concerned (Ongeri, Okioga, \& Okwena, 2013). It leads to exposure of responsibility on usage of public resources and accounting activities, thus requires proper attention from them. In order to provide quality accounting reports, the qualification and professionalism of staff should be supportive. The pressure and incentive of external surveillance such as legislative and government strong roles also drive the need for better financial reporting. According to Pina, Tores, and Royo (2010), socioeconomic condition influences the availability of resources and government capacity to implement a program or policy. Government fiscal capacity may influence the formulation and implementation of financial reporting policy. Financial capability helps in the execution and implementation of auditing policies to render appropriate accounting information.

\subsection{Empirical Review and Research Gaps}

Lumasei and Muturi (2019) studied factors influencing the performance of internal auditors in Kenya's county governments. They surveyed auditors across the 47 counties in Kenya. The study adopted both descriptive and inferential statistical analysis methods. Findings indicated that audit committee independence, affiliation to professional bodies, top management support, and availability of resources had a significant effect on the performance of internal auditors in County Governments. The study applied variables that could not have addressed the financial problems like financial distress concerning auditing role. Committee independence, affiliation to professional bodies, and top management support are not financial parameters. The current study applied auditing practices, particularly financial control frameworks and regulatory compliance in relation to financial distress among County Governments of Kenya.

Lekamario (2017) examined the factors affecting the quality of financial reporting of county governments in Kenya. The research performed a regression analysis to test the relationship of each of the four independent variables to the quality of financial reporting. The study found out that counties have effective and efficient recruitment systems in place and that staff was best suited to perform the job. Top management professional background and previous experience have a significant influence on the quality of financial reporting according to the study. IFMIS system was found to be reliable in the production of financial data for reports preparation. The regression analysis revealed that staff capacity significantly influenced the quality of financial reporting. All the other three variables had an influence on the quality of financial reporting but not as significant as staffing capacity. The study revealed that adequate training on the IFMIS system is necessary for the attainment of quality financial reporting. The research study was short of analysing risk assessment in auditing practices among County Governments. Risk assessment is an element of auditing that has been well discussed in the current study.

A research study by Ongeri, Okioga, and Okwena (2013) assessed the effectiveness of internal audit systems in the management of decentralized funds in Kenya. Data were analyzed using descriptive statistics such as frequency distributions, percentages, weighted averages, and results were presented using tables and graphs. Findings established that the internal audit systems were averagely effective in the management of LATF funds. The conclusions were scanty in describing financial distress since auditing was focused only on LATF funds. Additionally, LAFT belonged to defunct municipal and Councils. Auditing roles have changed with new constitution dispensation in Kenya. The current study examined the auditing practices in accordance to public financial management as guided by 2010 Kenya constitution.

Nyaga, Kiragu, and Riro (2018) conducted a study on the influence of internal audit independence on internal audit effectiveness in the Kirinyaga county government, Kenya. The findings indicated that the audit function was less than independent in evidence analyzed. Regression analysis revealed that internal audit independence had a positive and significant effect on internal audit effectiveness at $p$-value $\leq 0.05$. The study concluded that internal audit independence was an important predictor of the effectiveness of the audit function in the county government. External audit practices of regulatory frameworks, reporting standards, and supervisory activities were not included. External auditing is best positioned to explain the County's status regarding financial distress and was incorporated in the current study.

Musya (2014) studied the effect of internal controls on revenue collection by county governments in Kenya. 
The study findings established that weak internal controls activities and lack of proper information and communication systems had encouraged conspiracy to fraud, revenue loss, and embezzlement of collected revenue. The study did not address auditing governance. It also lacked the financial control frameworks in County Governments.

\section{Research Methodology}

\subsection{Research Design}

The research design refers to the framework of research that holds all of the aspects of a research project together (Bell, Bryman, \& Harley, 2018). It is the blueprint for conducting a research study intended to solve the existing problems in the area of study. This study adopted a descriptive survey design. Descriptive research design help in the collection of sufficient and relevant information for the research study. Furthermore, the descriptive research design entails the collection of data about prevailing conditions to infer and interpretation of results (Lakshmi \& Mohideen, 2013). It best suited this study in the analysis and establishment of the relationship between auditing practices and financial distress.

\subsection{Target Population}

According to Rea and Parker (2014) target population of the study is the population from which respondents are drawn, data collected from them, and study findings are generalized. This study was intended for Kenya's county governments with reference to financial distress that deterred effective service delivery. It targeted County Governments, particularly the five Counties that include; Nairobi, Nakuru, Kakamega, Meru, and Kilifi Counties. Auditors and accountants were involved in the study.

\subsection{Sample Size and Sampling Technique}

The sample is the subset representing the entire population intended for the study (Quinlan, Babin, Carr \& Griffin, 2019). Sampling is the process of selecting a sample of the respondents for the study in such a way that the individuals selected represent the population from which they were selected. The researcher used a proportionate stratified random sampling technique to obtain a sample of 103; 50 from ministries' strata and 53 from sub-county strata. The sample size was determined through Nasiuma's formula (2000). The population was divided into two strata; the respondents from the ministries who are 100 in number and 112 from the sub-counties. The sample size was calculated from each stratum and then added together to comprise the study's total sample.

Sample size was obtained as follows:

$$
\mathrm{n}=\frac{\mathrm{NC}^{2}}{\mathrm{C}^{2}+(\mathrm{N}-1) \mathrm{e}^{2}}
$$

Whereby;

$\mathrm{n}=$ Sample size

$\mathrm{N}=$ Population size

$\mathrm{C}=$ Coefficient of variation which is $50 \%$

$\mathrm{e}=$ Error margin which is 0.05

Substituting the values in the equation, the estimated sample size (n) was: Sample size for accountants and auditors in sub-counties

$$
\begin{aligned}
& \mathrm{n}=\frac{112(0.5)^{2}}{0.5^{2}+(112-1) 0.05^{2}} \\
& \mathrm{n}=53.080 \quad \mathrm{n}=53 \text { respondents }
\end{aligned}
$$

Sample size for accountants and auditors in County government ministries

$$
\mathrm{n}=\frac{100(0.5)^{2}}{0.5^{2}+(100-1) 0.05^{2}}
$$


$\mathrm{n}=50 \quad \mathrm{n}=50$ respondents

Total sample was; $53+50=103$ respondents

\subsection{Data Collection Instruments}

Data collection was done from the accountants and auditors of 5 selected County Governments. Questionnaires provide an opportunity for the adoption of practical ways in data gathering. According to Chatterjee and Hadi (2015), descriptive surveys are quantitative; thus, questionnaires are suitable for easy analysis of results. Therefore, the study used questionnaires to collect primary data from accountants and auditors.

\subsection{Data Analysis and Presentation}

According to Yin (2011), data analysis is the process of breaking complex information into smaller elements that can be easily clarified and understood. Data was analyzed by descriptive and inferential statistics. The study furthermore adopted inferential analysis applying Pearson correlation and regression analysis. The analysis was done with the aid of Statistical packages for social sciences (SPSS). The findings were presented by tables.

The following regression model was applied;

$\mathrm{Y}=\beta_{0}+\beta_{1} \mathrm{X}_{1}+\varepsilon$

Whereby;

$\mathrm{Y}=$ Financial Distress

$\beta_{0}=$ Constant (Coefficient of intercept of $\beta_{0}$ )

$\mathrm{X}_{1}=$ Auditing Practices

$\varepsilon=$ Error of Margin

\section{Findings and Discussions}

\subsection{Descriptive Findings for Auditing Practices and Financial Distress}

The researcher sought to determine whether existing auditing practices among county governments led to financial distress. Descriptive findings are presented on table 4.1.

Table 4.1: Influence of Auditing Practices on Financial Distress

\begin{tabular}{|c|c|c|c|c|c|c|c|c|}
\hline \multirow[t]{2}{*}{ Statement } & \multirow[t]{2}{*}{$\mathbf{n}$} & \multirow{2}{*}{$\begin{array}{l}\text { SD } \\
5\end{array}$} & & \multirow{2}{*}{$\mathbf{N}$} & \multirow{2}{*}{$\begin{array}{l}\text { D } \\
2\end{array}$} & \multirow{2}{*}{$\begin{array}{l}\text { SD } \\
1 \\
\end{array}$} & \multirow[t]{2}{*}{ Mean } & \multirow[t]{2}{*}{$\begin{array}{l}\text { Std. } \\
\text { Dev }\end{array}$} \\
\hline & & & & & & & & \\
\hline $\begin{array}{l}\text { 1. Assessment of risk and regulatory } \\
\text { compliance reduces chances of financial } \\
\text { distress. }\end{array}$ & 99 & $38.4 \%$ & $43.4 \%$ & $18.2 \%$ & - & - & 4.20 & .728 \\
\hline $\begin{array}{l}\text { 2. Regular and routine investigation of the } \\
\text { county books of accounts ensures } \\
\text { accountability. }\end{array}$ & 99 & $7.1 \%$ & $24.2 \%$ & $40.4 \%$ & $23.2 \%$ & $5.1 \%$ & 3.05 & .983 \\
\hline $\begin{array}{l}\text { 3. Effective auditing practices leads to } \\
\text { reliable financial reporting standards in } \\
\text { county governments. }\end{array}$ & 99 & $39.4 \%$ & $34.4 \%$ & $20.2 \%$ & $4 \%$ & $2 \%$ & 4.05 & .973 \\
\hline $\begin{array}{l}\text { 4. Insufficient control frameworks } \\
\text { contribute to financial distress. }\end{array}$ & 99 & $7.1 \%$ & $25.3 \%$ & $44.3 \%$ & $17.2 \%$ & $6.1 \%$ & 3.10 & .974 \\
\hline $\begin{array}{l}\text { 5. Adequate auditing supervisory activities } \\
\text { minimize financial distress. }\end{array}$ & 99 & $32.3 \%$ & $43.4 \%$ & $20.2 \%$ & $3 \%$ & $1 \%$ & 4.03 & .863 \\
\hline 6. Our auditing activities have adequate & 99 & $38.4 \%$ & $40.3 \%$ & $15.2 \%$ & $6.1 \%$ & - & 4.11 & .879 \\
\hline
\end{tabular}

Findings illustrated in Table 4.5 show that $81.8 \%$ of the involved accountants and auditors agreed (mean $=4.20$; std. $\mathrm{dev}=0.728$ ) that lack of appropriate risk and regulatory compliance in Kenya's county governments leads to financial distress. They argued that county governments lack a proper assessment of funds to avoid loss and wastage of public money. $40.4 \%$ had differing opinions (mean=3.05; std. dev=0.983) that accountability was determined by regular and routine investigation of the county books of accounts. The study of the county books of accounts may not have been done in a transparent manner, and loss of public funds was not revealed. Loss of public funds means that county governments will have little or no enough funds to settle their obligations hence 
financial distress. This explains the neutral response from the accountants and auditors. They further revealed (mean $=4.05 ;$ std. $\mathrm{dev}=0.973$ ) that reliable financial reporting standards depends on effective auditing practices and attributed financial distress to insufficient control frameworks among county governments. $44.3 \%$ of the respondents had differing opinions on whether inadequate control frameworks contributed to financial distress in County Governments of Kenya. There was a lack of clarity because County Governments lacked adequate control frameworks to establish their influence on financial distress. Additionally, control frameworks are about internal and external auditors who sometimes may not agree on some queries. Moreover, Respondents agreed $(\mathrm{mean}=4.03$; std. dev $=0.863$ ) that adequate supervisory activities minimize the challenges of financial distress. $38.4 \%$ and $40.3 \%$ strongly agreed and concurred respectively that their auditing activities had the support of the top county managements. Concerning the above findings, Unegbu (2011) revealed that local governments depend on auditors' findings and opinions. The auditors' deficiencies were the leading causes of financial mismanagement.

\subsection{Correlation between Auditing Practices and Financial Distress}

Correlation analysis findings for auditing practices and financial distress are presented on Table 4.2

Table 4.2: Correlation between Auditing Practices and Financial Distress

\begin{tabular}{llr}
\hline & & Financial Distress \\
\hline & Pearson Correlation & $.455^{* *}$ \\
Auditing Practices & Sig. (2-tailed) & .000 \\
& N & 99
\end{tabular}

**. Correlation is significant at the 0.01 level (2-tailed).

The association between auditing practices and financial distress was found to be positive, moderate and statistically significant $(\mathrm{r}=0.455 ; \mathrm{p}<0.01)$ at $1 \%$ level of significance. The financial distress can be attributed to poor risk assessment and lack of regulatory compliance by county governments. The financial reporting my not be reflecting the true financial status of the devolved units and they may not have adequate control frameworks as well. Furthermore, the auditing supervisory activities are not undertaken as required thus numerous challenges financial distress included.

\subsection{Regression Analysis for Auditing Practices and Financial Distress}

The study aimed at determining the relationship between auditing practices and financial distress among county governments of Kenya. Regression analysis was performed and findings are showed on Tables 4.3, 4.4 and 4.5.

Table 4.3: Model Summary for Auditing Practices and Financial Distress

\begin{tabular}{lcccc}
\hline Model & R & R Square & Adjusted R Square & Std. Error of the Estimate \\
\hline 1 & $.455^{\mathrm{a}}$ & .207 & .199 & .36880 \\
\hline
\end{tabular}

a. Predictors: (Constant), Auditing Practices

Table shows that there was a relationship between auditing practices and financial distress among County Governments of Kenya. The correlation coefficient was $\mathrm{R}=.455$. The coefficient of determination was $\mathrm{R}^{2}=.207$ implying that $20.7 \%$ variation in financial distress was caused by variation in auditing practices.

Table 4.4: ANOVA ${ }^{\mathrm{a}}$ for Auditing Practices and Financial Distress

\begin{tabular}{llccccc}
\hline Model & & Sum of Squares & df & Mean Square & F & Sig. \\
\hline \multirow{3}{*}{1} & Regression & 3.446 & 1 & 3.446 & 25.333 & $.000^{\mathrm{b}}$ \\
& Residual & 13.193 & 97 & .136 & & \\
& Total & 16.639 & 98 & & & \\
\hline
\end{tabular}

a. Dependent Variable: Financial Distress

b. Predictors: (Constant), Auditing Practices

Analysis of Variance was performed to determine whether the model was fit for the data. Results indicated a significant $\mathrm{F}$-value=25.333 that meant that model was fit for the data and all parameters of auditing practices influenced financial distress.

Table 4.5: Regression Coefficients ${ }^{a}$ for Auditing Practices and Financial Distress

\begin{tabular}{|c|c|c|c|c|c|}
\hline \multirow[t]{2}{*}{ Model } & \multicolumn{2}{|c|}{ Unstandardized Coefficients } & \multirow{2}{*}{$\begin{array}{c}\text { Standardized Coefficients } \\
\text { Beta }\end{array}$} & \multirow[t]{2}{*}{$\mathbf{t}$} & \multirow[t]{2}{*}{ Sig. } \\
\hline & B & Std. Error & & & \\
\hline (Constant) & 2.815 & .271 & & 10.374 & .000 \\
\hline Auditing Practices & .360 & .072 & .455 & 5.033 & .000 \\
\hline
\end{tabular}

a. Dependent Variable: Financial Distress

The following regression model was used; $Y=\beta_{0}+\beta_{1} X_{1}+\varepsilon$. Regression coefficients indicated that auditing practices had beta coefficient of .360 and t-value of 5.033. The relationship between auditing practices and financial distress was statistically significant at $1 \%$ significance level. The p-value was $.000<0.01$ implying that auditing practices influenced financial distress among County Governments of Kenya.In a bid to test the effect of auditing practices on financial distress, this hypothesis was stated. H01: Auditing practices does not significantly 
influence financial distress in county governments of Kenya. It was also rejected since the beta coefficient $(\beta=.360$; $\mathrm{p}=0.000<0.05)$ was significant at $95 \%$ confidence level. It can be stated that auditing practices contributes to financial distress based on the regression analysis findings.

\section{Summary of Findings}

Descriptive findings showed that internal and external auditing practices contributed to financial distress in the county governments of Kenya. Findings show that the lack of appropriate risk and regulatory compliance in Kenya's county governments leads to financial distress. They argued that most county governments lack a proper assessment of public money, thus difficult to avoid unnecessary losses. Financial reporting helps in monitoring of funds and planning to allocation in various activities meant for effective service delivery. Respondents revealed that reliable financial reporting standards depend on effective auditing practices and attributed financial distress to insufficient control frameworks among county governments. They stated that county governments needed increased top management support in supervisory activities to minimize the financial misappropriations in county governments. Correlation analysis indicated moderated a positive and significant association between auditing practices and financial distress in county governments of Kenya. It implied that financial distress in county governments could be attributed to a mismatch in financial reporting standards, below par risk assessment, and lack of adequate control frameworks regarding expenditures.

\section{Conclusion}

Based on the study findings, it can be concluded that internal and external auditing practices influence financial distress. County funds are siphoned from their accounts through inappropriate accounting procedures. This occurs due to a lack of proper assessment of regulatory compliance by the accountants and finance officers. The fruits of an investigation into reporting standards are not yet out, meaning that they are not being carried out in the required intensity. Funds are used for purposes that are of no importance to the county since there is no effective financial control and governance frameworks when the need for undertaking important activities such as payments to suppliers and employees, the county has no funds as they were already spent in unnecessary ways.

\section{References}

Alcaide-Munoz, L., Rodriguez Bolivar, M. P., \& Lopez Hernandez, A. M. (2017). Transparency in governments: A meta-analytic review of incentives for digital versus hard copy public financial disclosures. The American Review of Public Administration, 47(5), 550-573.

Bandy, G. (2014). Financial management and accounting in the public sector. Routledge.

Bell, E., Bryman, A., \& Harley, B. (2018). Business research methods. Oxford university press.

Brown, J., \& Dillard, J. (2013). Critical accounting and communicative action: On the limits of consensual deliberation. Critical Perspectives on Accounting. 24(3), 176-190.

Chatterjee, S., \& Hadi, A. S. (2015). Regression analysis by example. John Wiley \&Sons.

Hague, R., \& Harrop, M. (2013). Comparative government and politics: an introduction. Palgrave Macmillan.

Jacobs, K. (2012.) Making sense of social practice: Theoretical pluralism in public sector accounting research. Financial Accountability \& Management. 28;1, 267- 424.

Kuhlmann, S., \& Bogumil, J. (2018). Performance measurement and benchmarking as "reflexive institutions" for local governments: Germany, Sweden and England compared. International Journal of Public Sector Management, 31(4), 543-562.

Lakshmi, S., \& Mohideen, M. A. (2013). Issues in Reliability and Validity of Research. International journal of management research and reviews, 3(4), 2752.

Lehman, G. (2010). Perspectives on accounting, commonalities \& the public sphere. Critical Perspectives on Accounting. 21(8), 724-738.

Lekamario, J. L. (2017). Factors Affecting The Quality Of Financial Reporting Of County Governments in Kenya (Doctoral dissertation, Kca University).

Lin, Z. J., Yang, D. C., \& Wang, L. (2018). Accounting and auditing in China. Routledge.

Lumasei, K. F., \& Muturi, W. M. (2019). Factors Influencing Performance of Internal Auditors in County Governments in Kenya. Journal of Finance and Accounting, 3(4), 49-56.

Musya, F. M. (2014). The effect of internal controls on revenue collection by county governments in Kenya. Published MBA Report, University of Nairobi, Kenya.

Nassiuma, D. K., (2000). Survey sampling: Theory and methods.

Nyaga, K., Kiragu, D. N. U., \& Riro, G. K. (2018). Influence of internal audit independence on internal audit effectiveness in the kirinyaga county government, Kenya.

Odoyo, F. S., Adero, P., \& Chumba, S. (2014). Integrated financial management information system and its effect on cash management in Eldoret West District Treasury, Kenya.

Ongeri, S. N., Okioga, C., \& Okwena, D. K. (2013, February). An assessment of the effectiveness of internal audit 
systems in the management of decentralized funds in Kenya: A study of local authority transfer fund in Kisii Municipal Council. In Scientific Conference Proceedings.

Pina, V., Torres, L., \& Royo, S., (2010). Is e-government promoting convergence towards more accountable local governments? International Public Management Journal. 13(4), 350-380.

Quinlan, C., Babin, B., Carr, J., \& Griffin, M. (2019). Business research methods. South Western Cengage.

Rea, L. M., \& Parker, R. A. (2014). Designing and conducting survey research: A comprehensive guide. John Wiley \& Sons.

Schoeman, N. (2011). Fiscal Performance and Sustainability of Local Government in South Africa. An Empirical Analysis and Working paper 201. South Africa.

Unegbu, A. O., \& Kida, M. I. (2011). Effectiveness of internal audit as instrument of improving public Sector management. Journal of emerging trends in economics and management sciences, 2(4), 304-309.

Yilmz, S., Beris, Y. \& Serrano-Berthet, R. (2008). Local Government Discretion and Accountability: A diagnostic Framework for Local Governance. Local Governance Accountability Series, Paper No. 113

Yin, R. K. (2017). Case study research and applications: Design and methods. Sage publications. 